\title{
ANGGARAN PEMERINTAH DAERAH DALAM BINGKAI AMIN, AMAN, UMAN: SEBUAH STUDI SEMIOTIKA BARTHESIAN
}

\author{
Anjang Pranata \\ Gugus Irianto \\ Noval Adib \\ Universitas Brawijaya \\ anjanganjang@gmail.com
}

\begin{abstract}
This study aims to reveal the meaning of local government budget. The paradigm used in this research is interpretive by using Barthesian Semiotics research method. Semiotics Barthesian emphasizes the relationship between the sign with the individual experience and the culture of its users. Roland Barthes's ideas include the meaning of denotation, connotation and myth. The results reveal that the meaning of denotative local government budget is a plan embodied in monetary units. While the connotative meaning of local government budget is the result of agreement between the executive and legislative (amin). The preparation, execution, and reporting of the budget must comply with the prevailing laws and regulations (aman). Budgets are used to meet executive and legislative interests (uman). At the level of mythical budget is identified as an effort to welfare the community.
\end{abstract}

Keywords:

Budget; barthesian semiotics; denotative; connotative; myth

Anggaran merupakan bagian yang sangat penting dalam pemerintahan daerah. Dalam konteks akuntansi sektor publik, anggaran dapat dijadikan sebagai sumber informasi keuangan yang sangat penting (Halim \& Kusufi, 2012). Informasi keuangan berupa anggaran pada pemerintah daerah tersaji dalam bentuk sekumpulan angka dengan jumlah tertentu yang termuat di dalam APBD. Angka yang tercantum dalam anggaran pemerintah daerah adalah sebuah tanda ${ }^{1}$ yang didalamnya mengandung makna yang beragam. Keragaman dalam menafsirkan anggaran sangat mungkin terjadi. Contoh perbedaan tentang makna anggaran pemerintah daerah adalah perbedaan penafsiran antara Pemerintah provinsi (pemprov) Daerah Khusus Ibukota (DKI) sebagai pihak eksekutif dan Dewan Perwakilan Rakyat Daerah (DPRD) DKI sebagai pihak legislatif sehubungan dengan program e-budgeting. Reydonnyzar Moenek, Direktur Jenderal Keuangan Daerah Kemendagri selaku perwakilan pihak eksekutif, dalam sebuah wawancara dengan media, menyatakan "Belum ada kesamaan penafsiran antara legislatif dan eksekutif terhadap substansi APBD yang ingin disampaikan ke Mendagri untuk dievaluasi." (Aziza, 2015). Contoh lain perbedaan dalam memaknai anggaran antara eksekutif dan legislatif adalah pernyataan yang disampaikan Arif Wibowo, Kepala Badan Saksi Pemilu Nasional DPP PDI Perjuangan (legislatif) saat menanggapi kenaikan dana bantuan parpol yang dinilai masih terlalu kecil. "Sebenarnya Kementrian Dalam Negeri (Kemendagri) mengusulkan kenaikan Rp 5.000, tetapi Kementrian Keuangan (Kemenkeu) hanya menyetujui Rp 1000. Kemenkeu tidak mengerti politik." (Jawa Pos, 2017a). Dua contoh tersebut setidaknya menggambarkan bahwa ada perbedaan antara eksekutif dan legislatif dalam memaknai suatu anggaran. Semiotika Barthesian melihat bahwa perbedaan ini disebabkan oleh adanya perbedaan latar belakang pembaca (the reader) ${ }^{2}$ yakni eksekutif dan legislatif. Eksekutif melihat anggaran lebih kepada pertimbangan teknis. Sedangkan legislatif melihat anggaran lebih

\footnotetext{
${ }^{1}$ Tanda yang dimaksud pada penelitian ini adalah anggaran. Dalam pandangan semiotika, bila seluruh praktik sosial dapat dianggap sebagai fenomena bahasa, maka semuanya dapat juga dipandang sebagai tanda. Hal ini dimungkinkan karena luasnya pengertian tanda itu sendiri. (Piliang,1998:262).

${ }^{2}$ Pembaca (the reader) dalam penelitian semiotika Barthesian adalah orang yang menafsirkan sebuah tanda.
} 
kepada persoalan politis. Perbedaan dalam memaknai sebuah tanda tentunya tidak dapat dihindari, karena yang memberi makna tanda adalah manusia yang memiliki lingkungan sosial yang berbeda (Hoed, 2011). Perbedaan antara eksekutif dan legislatif dalam memaknai anggaran inilah yang memicu peneliti untuk melakukan penelitian tentang makna anggaran khususnya pada pemerintah daerah. Kondisi sosial budaya pada pemerintah daerah yang dinamis akan menghadirkan beragam makna tentang anggaran pada pemerintah daerah.

Penelitian mengenai anggaran dengan menggunakan pendekatan kualitatif telah dilakukan oleh Razak dkk. 2011 yang meneliti tentang perilaku yang berhubungan dengan kekuasaan eksekutif dan legislatif dalam penyusunan anggaran pemerintah daerah. Penelitian tersebut menggunakan metode interaksionisme simbolik yang merupakan bagian dari paradigma interpretif. Hasil penelitian menjelaskan bahwa dalam proses penganggaran telah terjadi pengaburan, dengan membangun pencitraan di hadapan publik menggunakan bahasa-bahasa hipokrit. Contoh penggunaan bahasa-bahasa hipokrit seperti "mencerdaskan kehidupan bangsa", "berjuang untuk rakyat kecil". Slogan-slogan tersebut biasa digunakan dalam kehidupan sehari-hari pada tingkat bahasa dan simbol-simbol politik dengan tujuan untuk menutupi realitas yang sesungguhnya. Penelitian Fakhry dkk. 2014 yang meneliti tentang perilaku aktor anggaran dalam proses penganggaran dengan menggunakan pendekatan teori interaksi simbolik yang dikembangkan dengan memadukan nilai-nilai kearifan lokal orang Mandar. Hasil penelitian menjelaskan bahwa terjadi perubahan paradigma dalam proses penganggaran pada pemerintah daerah. Saat dilakukan hearing antara eksekutif dan legislatif, kepentingan pribadi (self interest) aktor penyusun anggaran tersebut lebih mendominasi dibandingkan dengan kepentingan publik (public interest).

Sedangkan Wance \& Suranto, 2017) yang melakukan penelitian mengenai hubungan eksekutif dan legislatif pada proses penyusunan anggaran di pemerintah daerah, menemukan bahwa pada saat pembahasan APBD terdapat tiga pola interaksi eksekutif dan legislatif yaitu akomondasi, dominasi, dan kompromi. Pola interaksi eksekutif dan legislatif pada proses pembahasan di tingkat Panitia Anggaran dan tingkat komisi yang membidangi beberapa SKPD cenderung didominasi oleh pihak legislatif. Menurut Undang-Undang Nomor 23 Tahun 2014, hubungan kerja antara Kepala Daerah dengan DPRD merupakan hubungan kerja yang memiliki kedudukan setara dan bersifat kemitraan. Kedudukan setara artinya bahwa antar lembaga di pemerintahan daerah itu memiliki kedudukan yang sama dan sejajar. Hubungan kerja keduanya bersifat konstruktif dan bukan menjadi pesaing satu dan yang lainnya, dalam melaksanakan tugas dan fungsinya masing-masing.

Penelitian lain tentang anggaran khususnya mengenai dana aspirasi dengan menggunakan kajian etno-semiotika berdasarkan filsafat Roland Barthes yang termasuk paradigma interpretifkritis telah dilakukan oleh (Pasoloran, 2016). Hasil penelitian berhasil mengungkap bahwa anggaran pemerintah daerah belum sepenuhnya berorientasi pada kepentingan masyarakat; dana aspirasi masyarakat sebagai sebuah wacana dan realitas sengaja diciptakan dan direproduksi oleh aktor anggaran untuk kepentingan pribadi dan politik; secara denotatif dana aspirasi masyarakat oleh legislatif dimaknai sebagai salah satu bentuk kebijakan yang bertujuan untuk pemerataan kesejahteraan masyarakat berdasarkan daerah pemilihan, kemudian pada tingkat konotatif dana aspirasi masyarakat dimaknai sebagai dana titipan, dana politis, aspirasi dan inspirasi aktor penyusun anggaran. Dana aspirasi berubah menjadi mitos yang seolah-olah menjadi sangat alamiah sebagai wujud dari pelaksanaan kewajiban aktor penyusun anggaran.

Perbedaan penelitian ini dengan penelitian sebelumnya terletak pada pemilihan topik dan metode penelitian. Topik penelitian tentang anggaran sudah banyak dilakukan namun lebih banyak didominasi oleh penelitian-penelitian yang melihat anggaran dari sudut pandang stastistik dan mekanistik semata. Penelitian-penelitian tentang anggaran pada umumnya dilakukan dengan pendekatan-pendekatan positivistik seperti yang dilakukan oleh (Erina \& Suartana, 2016; Rahardjo, 2009; Usman \& Paranoan, 2013; Wahyuningsih \& Pramuka, 2012) yang meneliti tentang anggaran partisipatif. Sementara (Riharjo \& Isnadi, 2010) meneliti tentang perilaku oportunistik pejabat eksekutif dalam menyusun APBD dengan menggunakan teori keagenan. Oleh karena itu pada penelitian ini mencoba untuk mencari sudut pandang lain dengan memilih topik anggaran yang 
mengkhususkan pada penelitian tentang makna anggaran. Adapun dari sisi metode, untuk penelitian tentang makna lebih banyak menggunakan studi fenomenologi yang termasuk dalam paradigma interpretif. Studi fenomenologi menggambarkan suatu makna secara mendalam, didapatkan dari beberapa individu yang mempunyai pengalaman hidup yang berhubungan dengan sebuah konsep tertentu. Peneliti mereduksi apa yang dialami oleh individu tersebut kedalam sebuah esensi yang bersifat universal (Creswell, 2014). Beberapa penelitian tentang makna suatu konsep dengan pendekatan fenomenologi dilakukan oleh (Arfiansyah, 2016; Sopanah, 2009; Yanuarisa, Rosidi, \& Irianto, 2014) yang meneliti penyusunan anggaran pada pemerintah daerah. Pada penelitian ini, peneliti menggunakan metode semiotika Barthesian untuk meneliti tentang makna anggaran. Dengan menggunakan metode tersebut peneliti mencoba untuk mengungkap makna anggaran pemerintah daerah melalui beberapa tingkatan makna yakni denotatif, konotatif dan mitos.

Diskursus mengenai anggaran pada pemerintah daerah menjadi menarik untuk dikaji. Proses interaksi antara aktor yang terlibat dalam praktik penganggaran pada pemerintah daerah memberikan inspirasi bagi peneliti untuk meneliti tentang makna anggaran.Tujuan dari penelitian ini adalah untuk mengungkap makna anggaran oleh eksekutif dan legislatif pada pemerintah daerah. Keragaman makna tentang anggaran yang muncul selama proses penelitian akan menjadi makna tersendiri bagi peneliti dan masyarakat pada umumnya dalam memahami makna anggaran pada pemerintah daerah. Pemahaman penafsiran oleh aktor-aktor yang terlibat dalam proses penganggaran akan menjadi modal bagi eksekutif maupun legislatif untuk dapat berkomunikasi dengan baik. Sehingga proses penganggaran pada pemerintah dapat berjalan dengan baik dan bermanfaat bagi masyarakat.

\section{METODE}

Penelitian ini menggunakan metode semiotika Barthesian. Semiotika merupakan metode penelitian yang digunakan untuk mengkaji tentang tanda. Tanda yang dimaksud dalam penelitian ini adalah anggaran. Semiotika adalah salah satu pendekatan dalam penelitian yang termasuk dalam domain paradigma interpretif (Djamhuri, 2012). Ciri dari paradigma interpretif adalah penekanan terhadap suatu upaya pengkonstruksian dan penafsiran suatu tindakan masyarakat baik dari pengetahuan yang mereka miliki maupun pengalaman yang telah mereka lakukan dalam suatu tindakan sosial. Tujuan dari paradigma interpretif adalah untuk menemukan suatu makna yang tersembunyi dari berbagai tindakan sosial dari apa yang dipahami oleh pelaku atau aktor yang berperan melalui suatu upaya pemahaman yang searah dan baik. Paradigma intepretif berupaya untuk melakukan konstruksi ulang terhadap struktur sosial ketika interaksi sosial sedang berlangsung dengan pamahaman keseluruhan aktor yang terlibat.

Penerapan semiotika dalam akuntansi disebabkan karena akuntansi dapat disebut sebagai sebuah bahasa, karena akuntansi memiliki karakteristik leksikal maupun gramatikal (Belkaoui, 1980). Dengan karakteristik tersebut, akuntansi dapat diartikan sebagai seperangkat simbol bahasa atau representasi simbolik yang menunjuk pada suatu makna atau realitas tertentu. Gagasan bahwa akuntansi dapat dilihat sebagai bahasa telah menghasilkan berbagai upaya empiris untuk mengevaluasi makna konotatif dan denotatif konstruksi akuntansi. Karena dapat dilihat sebagai bahasa, akuntansi telah diteliti menggunakan teori dan metode yang digunakan dalam studi bahasa (Belkaoui, 1989). Akuntansi merupakan sebuah bahasa. Akuntansi adalah bahasa bisnis yang didalamnya terdapat tanda berupa teks dan angka-angka yang berhubungan dengan berbagai kemungkinan penafsiran bagi pembaca laporan keuangan (Hendriksen \& Van Breda, 1992). Saat akuntansi dilihat sebagai bahasa bisnis, maka akuntansi dapat dihubungkan dengan semiotika. Semiotika merupakan bidang ilmu yang mempelajari tentang bahasa, dan ini sangat membantu dalam penelitian akuntansi, dengan hubungan antara pengguna dan sistem normatif sebagai contoh dari fokus penelitian yang mungkin dilakukan (Fontana, 2013). 
Semiotika merupakan cabang keilmuan yang mempelajari tentang tanda-tanda (signs), sistem tanda, dan cara bagaimana suatu makna ditarik dari tanda-tanda tersebut. Apapun yang mengatakan kepada kita tentang sesuatu yang lain daripada dirinya sendiri adalah tanda (Gordon, 2002). Contoh tanda yang sering kita temui dalam kehidupan sehari-hari kita adalah teks dalam sebuah bacaan, angka, grafik, rambu-rambu lalu lintas, gejala alam, ekspresi manusia, dan sebagainya. Semiotika adalah studi tentang tanda dan cara tanda itu bekerja (Fiske, 2007). Semiotika menganggap bahwa fenomena sosial yang terjadi di masyarakat dan kebudayaan itu merupakan tanda. Semiotika secara resmi memiliki suatu perkumpulan ilmiah, yaitu International Association for Semiotic Studies (IAAS) sejak tahun 1969. Pada tahun 1988 didirikan lembaga penelitian international tentang semiotika yaitu International Semiotics Institute yang berkedudukan di berbasis di Kaunas University of Technology (Lithuania). Lembaga penelitian ini dikhususkan untuk mempelajari dan mengembangkan semiotika, dalam arti yang paling interdisipliner.

Metode semiotika yang digunakan dalam penelitian ini adalah semiotika yang berdasarkan pada pemikiran Roland Barthes, atau dikenal dengan sebutan semiotika Barthesian. Semiotika Barthesian digunakan peneliti untuk mengungkap makna anggaran pada tingkatan denotatif, konotatif dan mitos. Salah satu hal yang sangat penting pada semiotika Barthesian adalah peran pembaca (the reader) yang berhubungan dengan tanda. Roland Barthes menjelaskan hubungan antara tanda dengan pengalaman pribadi dan budaya penggunanya. Berikut model semiotika yang berdasarkan pada pemikiran Roland Barthes.

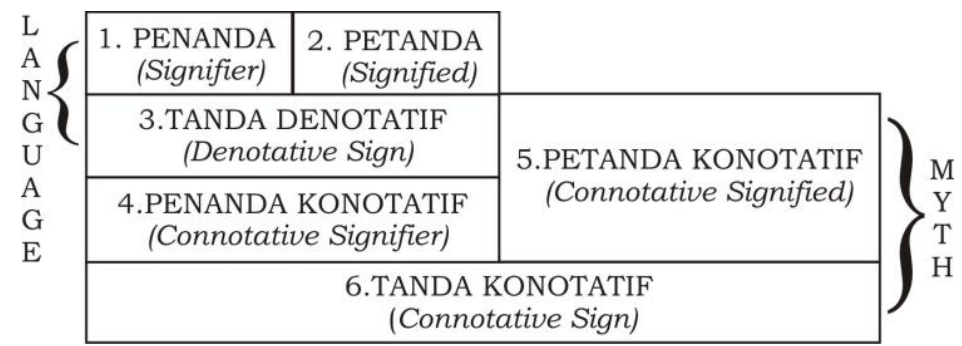

\section{Gambar 1. Model Semiotika Barthesian}

Sumber: diadaptasi dari Barthes 1957 dalam Chandler, 2007:140

Penanda merupakan aspek material dari suatu tanda yakni sesuatu yang diucapkan atau didengar dan apa yang tertulis atau terbaca. Petanda adalah gambaran mental, pikiran, atau konsep. Sebagai contoh kata "anjing" merupakan penanda dari petanda (konseptual) hewan yang bertaring, berkaki empat, menggigit, bergigi tajam, ekornya selalu bergoyang, menggongong, dan kencing disembarang tempat. Sebuah penanda tanpa petanda tidak tidak akan memiliki arti apa-apa. Begitu juga sebaliknya, suatu petanda tidak mungkin dapat disampaikan atau dilepaskan dari penanda. Penanda dan petanda merupakan satu kesatuan yang tidak dapat dipisahkan, seperti dua sisi dari sehelai kertas (lihat gambar 2).

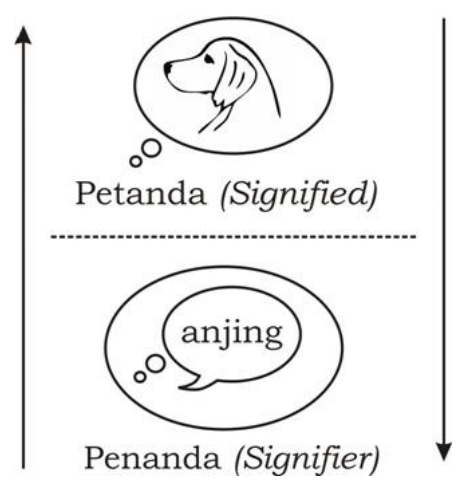

Gambar 2. Hubungan Penanda (Signifier) dan Petanda (Signified) 
Denotatif adalah makna yang sesungguhnya atau makna umum yang sudah menjadi kesepakatan bersama. Teori semiotika Barthesian, menjelaskan denotatif merupakan bagian dari sistem pemaknaan tataran pertama. Pada tahap ini dijelaskan hubungan antara penanda dan petanda dalam sistem tanda, dan antara tanda dengan objek yang diwakilinya dalam realitas ekternalnya. Sedangkan konotatif adalah istilah yang digunakan Roland Barthes untuk menjelaskan salah satu dari cara kerja tanda pada tataran kedua signifikasi tanda (two order of signification). Konotatif menjelaskan hubungan yang terjadi saat tanda bertemu dengan perasaan atau emosi dari pengguna dan budaya pengguna tanda. Denotatif adalah apa yang digambarkan terhadap subjek sedangkan konotatif mempunyai nilai subyektif atau intersubyektif. Konotatif adalah bagaimana menggambarkannya. Pada tahap kedua, signifikasi berhubungan dengan isi, tanda dan bekerja melalui mitos (myth). Mitos merupakan bentuk signifikasi yang berada pada tingkat kedua, teori mitos di kembangkan Barthes sebagai kritik atas ideologi budaya massa (Sunardi, 2007).

Informan penelitian. Fokus penelitian ini adalah mengungkap makna anggaran pada pemerintah daerah. Informan penelitian terdiri dari eksekutif dan legislatif yang berpengalaman dalam proses penyusunan anggaran daerah. Berdasarkan kesepakatan dengan informan, maka nama-nama informan serta informasi yang bersifat 'rahasia', disamarkan, dengan tidak mengurangi substansi tentang makna anggaran. Berikut data informan untuk penelitian tentang makna anggaran.

Tabel 1. Informan Penelitian

\begin{tabular}{|l|l|}
\hline \multicolumn{1}{|c|}{ Identitas Informan } & \multicolumn{1}{|c|}{ Posisi/Jabatan dalam Organisasi } \\
\hline Bapak Hamzah & Kepala OPD $^{3}$ X \\
\hline Ibu Sisca & Proglap OPD X \\
\hline Bapak Utama & Inspektorat \\
\hline Bapak Maulana & Pejabat Penyedia Barang dan Jasa \\
\hline Bapak Angga & Tim Anggaran , Asisten Pemerintahan \\
\hline Bapak Samuel & Sekretaris Dewan \\
\hline Bapak Handy & $\begin{array}{l}\text { Kepala Bidang Analisis Perencanaan Pengendalian Pelaporan } \\
\text { Pembangunan Badan Perencanaan, Penelitian dan Pembangunan } \\
\text { Daerah }\end{array}$ \\
\hline Ibu Heriyati & Kepala Bidang Anggaran \\
\hline Legislatif & Wakil Ketua Badan Anggaran , Partai Hijau \\
\hline Bapak Firman & Wakil Ketua Badan Anggaran, Partai Merah \\
\hline Bapak Suryanto & Ketua Komisi, Partai Kuning \\
\hline Bapak Andriono & Anggota Badan Musyawarah, Partai Biru \\
\hline Bapak Fitrah & \\
\hline
\end{tabular}

Data yang didapatkan berupa hasil wawancara mendalam (indepth interview) dengan eksekutif dan legislatif. Data lainnya berupa hasil observasi peneliti terhadap budaya, peraturan dan perundangan-undangan yang berhubungan dengan anggaran pada pemerintah daerah. Adapun tahapan-tahapan penelitian dengan metode semiotika Barthesian dapat dilihat pada gambar 3.

\footnotetext{
${ }^{3}$ OPD adalah Organisasi Perangkat Daerah, dulu disebut dengan SKPD (Satuan Kerja Perangkat Daerah)

${ }^{4}$ Tim Anggaran adalah tim yang dibentuk dengan keputusan kepala daerah dan dipimpin oleh sekretaris daerah yang mempunyai tugas menyiapkan serta melaksanakan kebijakan kepala daerah dalam rangka penyusunan APBD yang anggotanya terdiri dari pejabat perencana daerah, PPKD dan pejabat Iainnya sesuai dengan kebutuhan

${ }^{5}$ Badan Anggaran adalalah tim yang dibentuk oleh DPRD bertugas memberikan saran dan pendapat berupa pokok-pokok pikiran DPRD kepada kepala daerah dalam mempersiapkan rancangan anggaran pendapatan dan belanja daerah sebelum ditetapkannya APBD;
} 


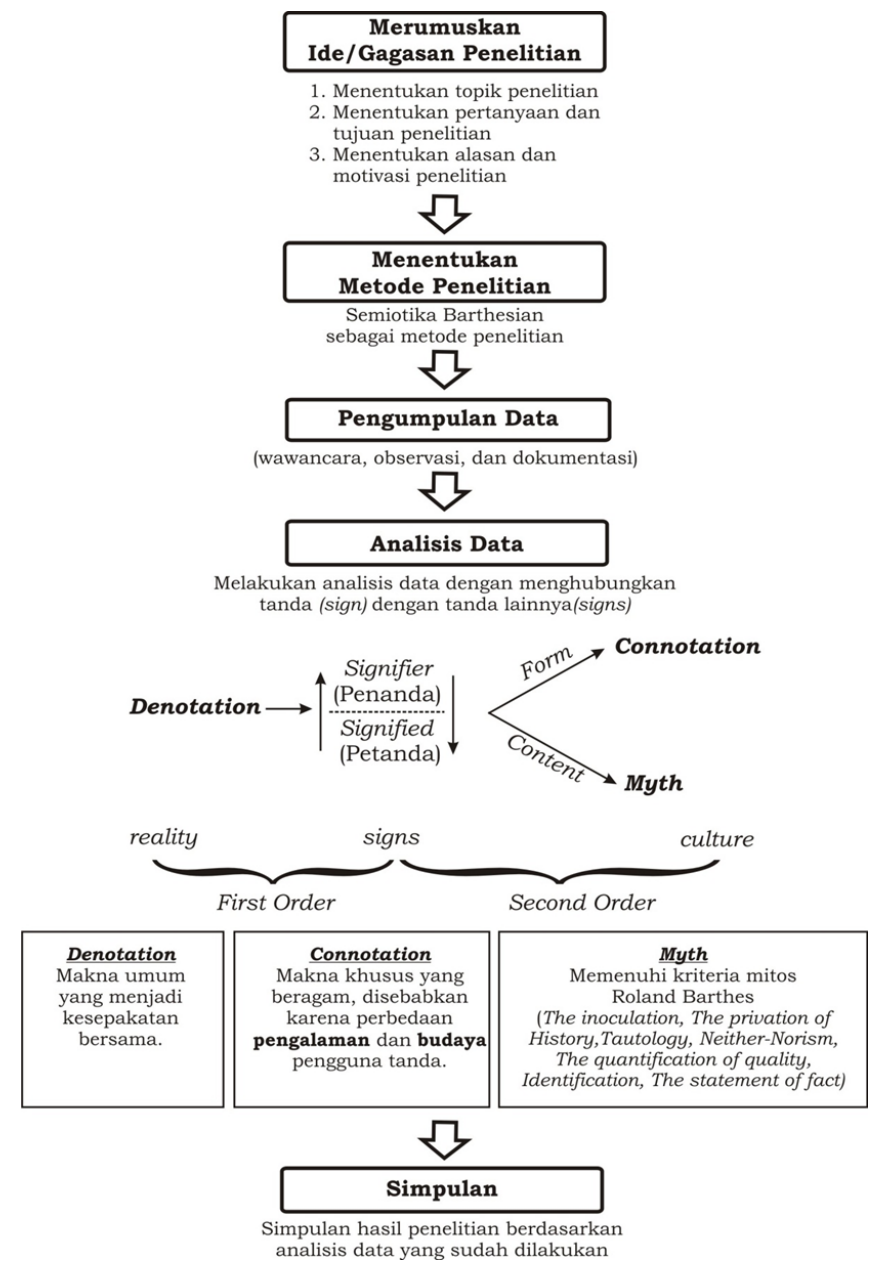

Gambar 3. Tahapan penelitian dengan pendekatan Semiotika Barthesian

Untuk mengungkap makna konotatif suatu tanda, seorang peneliti harus memahami unsurunsur tanda tersebut dalam sebuah totalitas dan menghubungkannya dengan nilai budaya dalam suatu masyarakat. Sedangkan untuk bisa mendeteksi suatu tanda yang berkembang menjadi mitos dapat menggunakan ciri-ciri mitos yang ditulis oleh Roland Barthes dalam bukunya yang berjudul Mythologies (Barthes, 1957), yakni: 1. The Inoculation, yakni menerima sedikit 'kejelekan' dalam satu institusi sehingga menyingkirkan kesadaran tentang adanya masalah yang lebih mendasar. Misalnya oknum anggota DPRD terlibat kasus korupsi; 2. The Privation of History, yaitu sebuah usaha untuk mewujudkan identitas baru dengan meninggalkan sejarah masa lalu. Contoh: Menuju era baru yang lebih maju; 3.Tautology, merupakan suatu pernyataan yang sudah menjadi kebiasaan dan tidak perlu diperdebatkan lagi. Isi dari sebuah pernyataan direduksi ke dalam sebuah tampilan. Contoh: kalimat "ya, sudah begitu dari sananya", "Lali jenenge eling rasane", "Percayalah apa yang dikatakan..."; 4. Neither-norism, merupakan suatu tindakan yang tidak memihak atau tidak berani memilih, dan menganut opini pada posisi di tengah. Contoh: Golput, Gerakan Non Blok, Demokrasi, Multiparadigma dan sebagainya. 5. The Quatification of quality, upaya mereduksi kualitas ke dalam kuantitas. Semua perilaku manusia, dan realitas sosial direduksi menjadi nilai kuantitas. Contoh: Angka kemiskinan, pertumbuhan ekonomi. 7. Identification, yaitu mereduksi perbedaan atau ciri khas yang menjadi identitas dasar. Contoh: sarung identik dengan kaum santri, "Orang pintar minum...", semua agama sama, dan sebagainya. Dan 8. The statement of fact, yaitu suatu kebiasaan yang sudah menjadi pendapat umum, segala sesuatu tidak lebih dari penampakannya. Contoh: "Anggaran harus pro rakyat". 


\section{HASIL DAN PEMBAHASAN}

Setiap tanda akan memunculkan sebuah makna. Makna tersebut muncul karena adanya interaksi antara penanda (signifier) dan petanda (signified). Munculnya makna suatu tanda juga disebabkan karena adanya perbedaan persepsi oleh perasaan dan pikiran pengguna tanda. Dengan menggunakan perasaan dan akal pikirannya seseorang akan menghubungkan suatu tanda dengan rujukannya (reference) untuk mendapatkan makna tanda tersebut. Oleh karena itu pengalaman individu dan budaya pengguna tanda menjadi sangat penting dalam penelitian semiotika. Pengalaman individu dan budaya penggguna tanda akan mempengaruhi bagaimana seseorang memaknai sebuah tanda. Peneliti melakukan pembacaan (analisis) terhadap data yang sudah diperoleh yakni hasil wawancara, observasi lapangan, peraturan dan perundang-undangan yang berhubungan dengan anggaran pada pemerintah daerah.

Perbedaan eksekutif dan legislatif dalam memaknai anggaran pada pemerintah didaerah adalah hal yang wajar. Perbedaan pengalaman individu dan budaya, menimbulkan persepsi yang berbeda-beda dalam memaknai anggaran. Perbedaan dalam memaknai anggaran ini disadari betul, baik oleh eksekutif maupun legislatif. Pak Hamzah (56 tahun) yang sebelumnya menjabat sebagai kepala OPD X dan pernah menjabat sebagai sekretaris dewan menyampaikan:

“...ya, kalo eksekutif melihat anggaran lebih kepada persoalan teknis, sedangkan

legislatif lebih kepada politis, ya...itu kan juga terkait dengan konstituennya juga..."

Kesadaran akan perbedaan dalam memaknai anggaran antara eksekutif dan legislatif ini juga disampaikan oleh Bapak Cahyo, Ketua DPRD kota yang peneliti kutip dari http://agropolitantv.co.id, berikut pernyataannya:

“..Segala perjuangan untuk kepentingan masyarakat, terlebih dahulu harus dikomunikasikan dengan seluruh anggota fraksi, untuk menyamakan persepsi, visidan misinya...(Agropolitannews, 2017)

Eksekutif melihat anggaran dari sudut pandang teknis yakni bagaimana suatu anggaran dilihat sebagai sebuah bentuk perencanaan yang diwujudkan dalam satuan moneter untuk mencapai tujuan tertentu. Aspek-aspek teknis seperti pendekatan yang digunakan, peraturan perundangundangan, sistem penganggaran menjadi hal seringkali kita jumpai dalam proses penganggaran yang dilakukan oleh eksekutif.

Sedangkan legislatif melihat suatu anggaran dari sudut pandang politis. Sebagai salah satu aktor yang terlibat dalam suatu pengganggaran, legislatif menggunakan anggaran untuk memenuhi kepentingannya. Anggaran digunakan legislatif tidak hanya digunakan untuk memenuhi kepentingan masyarakat pada umumnya. Namun juga digunakan untuk memenuhi kepentingan konstituennya. Legislatif menggunakan anggaran untuk mewujudkan aspirasi masyarakat yang diwujudkan dalam fungsinya sebagai wakil rakyat. Perbedaan latar belakang dari sudut pandang teknis dan politis inilah yang menjadi salah satu penyebab perbedaan penafsiran anggaran pada pemerintah daerah. Dari hasil pembacaan terhadap data penelitian dengan menggunakan semiotika Barthesian didapat hasil penelitian sebagai berikut.

\section{Kesepakatan Makna Anggaran}

Semiotika Barthesian menjelaskan bahwa makna denotatif merupakan bagian dari sistem pemaknaan tataran pertama. Pada tahap ini dijelaskan hubungan antara penanda dan petanda dalam sistem tanda, dan antara tanda dengan objek yang diwakilinya dalam realitas ekternalnya. Makna denotatif biasanya mengacu pada definisi yang ada di dalam kamus atau peraturan perundang undang-undangan yang berlaku. Makna denotatif merupakan makna pada umumnya yang merupakan hasil kesepakatan para pengguna tanda. Dari hasil wawancara dengan eksekutif dan legislatif didapatkan sebuah kesepakatan bahwa yang dimaksud dengan anggaran adalah dana atau uang dalam satuan tertentu yang digunakan untuk tujuan tertentu. Pernyataan bahwa anggaran merupakan sejumlah dana yang digunakan untuk pelaksanaan pembangunan disampaikan oleh Ibu Heriyati yang saat ini menjabat sebagai Kepala Bidang Anggaran Badan Keuangan Daerah. 
"Anggaran merupakan persediaan dana yang digunakan untuk pelaksanaan pembangunan"

Senada dengan pernyataan diatas bahwa anggaran identik dengan dengan sejumlah uang untuk membiayai program dan kegiatan pembangunan disampaikan oleh Bapak Handy (41 tahun), Kepala Bidang Analisis Perencanaan Pengendalian Pelaporan Pembangunan Badan Perencanaan, Penelitian dan Pembangunan Daerah

"Anggaran adalah dana pembangunan...dana pembangunan adalah sumber pembiayaan dalam bentuk uang, dalam bentuk pinjaman atau apa? yang digunakan untuk membiayai proyek-proyek dan kegiatan pembangunan...sumber dana penbiayaan itulah yang kami sebut dengan anggaran "

Sedangkan dari hasil wawancara dengan pihak legislatif yang di wakili Bapak Firman, Wakil Ketua Badan Anggaran yang sekaligus juga sebagai Ketua Umum Partai Hijau menyatakan bahwa:

"Yang dimaksud dengan anggaran adalah keuangan, pembiayaan yang digunakan untuk membiayai kegiatan dalam mencapai target yang ditetapkan".

Tidak jauh berbeda dari hasil wawancara dengan eksekutif dan legisalatif diatas, menurut Kamus Besar Bahasa Indonesia, definisi anggaran adalah rencana penjatahan sumber daya yang dinyatakan dengan angka, biasanya dalam satuan uang. Sedangkan menurut Permendagri ${ }^{6}$ Nomer 31 tahun 2016 tentang Penyusunan Anggaran Pendapatan dan Belanja Daerah tahun anggaran 2017 menyebutkan bahwa yang dimaksud dengan anggaran adalah rencana tahunan pemerintah daerah yang dibahas dan disetujui bersama oleh pemerintah daerah dan DPRD, dan ditetapkan dengan peraturan daerah. Jadi dapat disimpulkan bahwa secara denotatif yang dimaksud dengan anggaran adalah perencanaan dalam bentuk satuan moneter yang digunakan untuk mencapai tujuan tertentu. Atau secara sederhana dapat dikatakan bahwa anggaran diidentikkan dengan perencanaan, dana atau uang, dan tujuan tertentu.

\section{Keragaman Makna Anggaran}

Keragaman makna dalam teori semiotika Barthesian disebut dengan konotatif. Barthes menyatakan bahwa konotatif merupakan sistem pemaknaan tataran kedua, yang menjadi bagian tak terpisahkan dari dari sistem lain yang sudah ada sebelumnya. Makna konotatif lebih bersifat subjektif, dalam arti bahwa terdapat pergeseran dari makna pada umumnya (denotatif) karena adanya penambahan rasa dan nilai tertentu. Seorang peneliti harus memahami unsur-unsur tanda untuk mengungkap makna konotatif suatu tanda. Hubungan antara unsur-unsur tanda dalam sebuah totalitas dan menghubungkannya dengan nilai budaya dan pengalaman individu pengguna tanda tersebut. Dari hasil wawancara, telaah pustaka dan peraturan perundang-undangan yang berlaku serta berdasarkan hasil pengamatan terhadap nilai budaya dan pengalaman individu eksekutif dan legislatif, maka didapatkan makna konotatif anggaran pemerintah daerah sebagai berikut:

\section{a. Anggaran sebagai hasil kesepakatan antara eksekutif dan legislatif (amin)}

Anggaran pada pemerintah daerah merupakan hasil dari kesepakatan antara eksekutif dan legislatif yang diwujudkan dalam bentuk Anggaran Pendapatan dan Belanja Daerah. Hasil kesepakatan antara eksekutif dan legislatif tersebut dapat diwakili oleh sebuah tanda yakni kata "amin". "Amin", berasal dari bahasa Arab 'amīn' yang berarti orang yang amanah. Kata 'amin' biasa diucapkan seseorang pada bagian akhir sebuah do'a. Sebagai harapan bahwa do'a yang dipanjatkan dikabulkan. Dalam terminologi bahasa dan nilai budaya jawa kata 'amin' dapat diartikan sebagai sebuah persetujuan. Sebagai contoh kalimat "Perintah Jokowi Hindari Hujatan dan Fitnah Diamini DPR" (Jawa Pos, 2017b), yang dapat diartikan bahwa DPR menyetujui apa yang disampaikan oleh Presiden Jokowi.

\footnotetext{
${ }^{6}$ Setiap akhir tahun Kementrian Dalam Negeri menerbitkan peraturan yang berhubungan dengan penyusunan anggaran pada pemerintah daerah sebagai pedoman untuk penyusunan anggaran tahun berikutnya
} 
Hubungan kata 'amin' dengan anggaran pada pemerintah daerah bisa ditafsirkan sebagai sebuah kesepakatan antara eksekutif dan legislatif dalam menyusun anggaran pada pemerintah daerah. Hasil kesepakatan tersebut kemudian ditetapkan dalam peraturan daerah tentang APBD. Pernyataan Bapak Suryanto (50 tahun) sebagai wakil ketua Badan Anggaran menyatakan bahwa anggaran yang nantinya akan ditetapkan dalam bentuk Perda APBD merupakan hasil kesepakatan antara eksekutif dan legislatif. Persetujuan terhadap Rancangan Anggaran dan Belanja Daerah (RAPD). Alasan legislatif tidak menyetujui atau menyetujui anggaran yang diajukan oleh eksekutif, nampak pada wawancara berikut ini.

“...alasan kita menyetujui adalah karena itu sudah jadi visi dan misi walikota, sudah tercantum dalam RPJMD,...anggaran yang disodorkan kepada Banggar disetujui karena berpihak kepada masyarakat... untuk kepentingan masyarakat...mengapa kok tidak disetujui, berarti ada kesalahan-kesalahan di situ, tidak berpihak kepada masyarakat, tidak sesuai dengan visi dan misi walikota...kok diusulkan...kalo kita menyetujui malah salah..."

Tarik ulur untuk mendapatkan sebuah kesepakatan (amin) merupakan hal yang wajar terjadi dalam proses penyusunan anggaran daerah. Adanya tarik ulur dalam proses penganggaran disebabkan karena antara eksekutif dan legislatif memiliki kepentingan yang berbeda-beda. Eksekutif dan legislatif pada pemerintah daerah Kota Balakoma dapat bekerjasama dengan baik pada saat proses penyusunan anggaran. Hal ini disampaikan oleh Bapak Handy yang menjabat sebagai Kepala Bidang Analisa, Pengendalian dan Pelaporan Perencanaan. Pembangunan Kota Balakoma.

"Alhamdulillah, kalau dikota Balakoma itu konstruktif positif,...dalam arti..ee...kita sebagai eksekutif bisa bekerjasama sangat baik dengan teman-teman yang legislatif melalui banggar..."

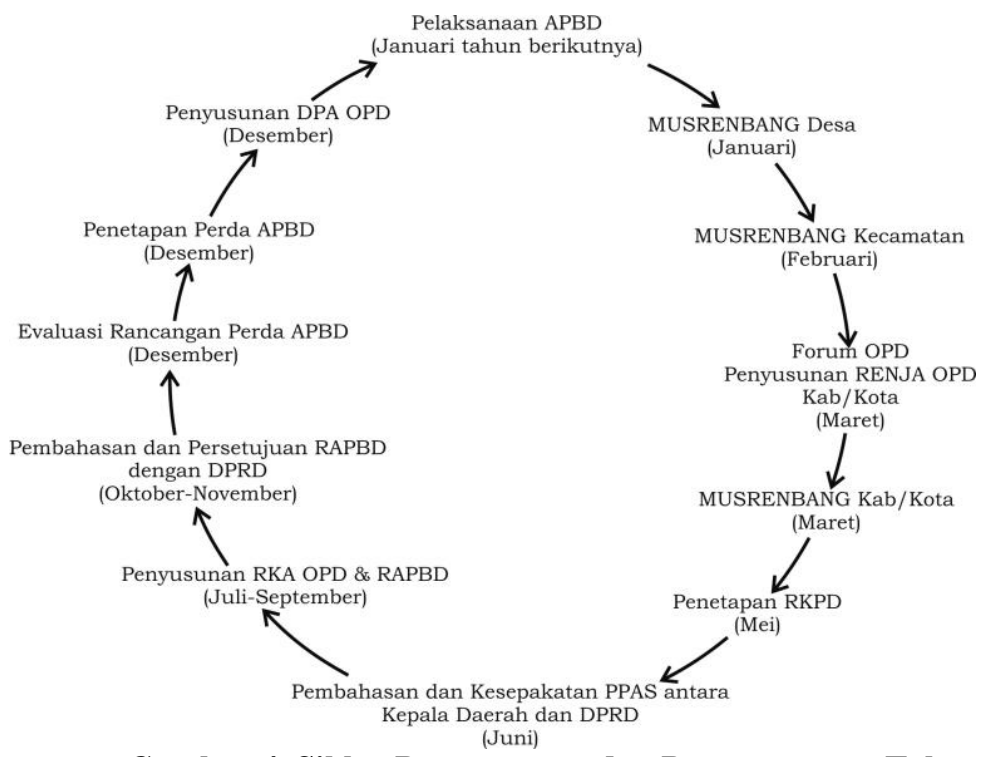

Gambar 4. Siklus Perencanaan dan Penganggaran Tahunan

Proses 'peng-amin-an' anggaran tidak hanya terjadi pada saat penetapan APBD saja, namun proses 'peng-amin-an' itu dilakukan sejak saat penjaringan aspirasi, baik itu melalui musrenbang ${ }^{7}$ maupun pada masa reses $^{8}$ sampai dengan penetapan APBD. Pada tahap

\footnotetext{
${ }^{7}$ Musrenbang adalah singkatan dari Musyawarah dan Perencanaan Pembangunan, dilakukan eksekutif untuk menjaring aspirasi masyarakat dan diadakan secara bertahap mulai tingkat desa, kecamatan sampai kabupaten/kota.
} 
penyusunan rencana kerja di tingkat OPD pun juga diperlukan 'peng-amin-an". Setiap OPD akan melakukan pembahasan mengenai rencana kerja dengan seluruh bidang yang akan melaksakan program dan kegiatan OPD. Setelah tersusun rencana kerja OPD, akan dilakukan pembahasan dengan Tim Anggaran yang sudah dibentuk oleh kepala daerah. Baru setelah itu dilakukan pembahasan antara Tim Anggaran dan Badan Anggaran yang sudah dibentuk oleh DPRD. Hasil kesepakatan antara eksekutif dan legislatif tersebut kemudian ditetapkan melalui peraturan daerah tentang APBD. Lihat siklus perencanaan dan penganggaran pada gambar 4.

b. Penyusunan, pelaksanaan, dan pelaporan Anggaran harus mentaati peraturan dan perundang-undangan yang berlaku (aman).

Anggaran merupakan perencanaan dalam bentuk satuan moneter yang digunakan untuk melaksanakan program dan kegiatan dalam satu periode tertentu. Bagi pemerintah daerah anggaran merupakan bagian yang sangat penting dan mempengaruhi perjalanan suatu pemerintahan. Dengan adanya anggaran, program dan kegiatan yang dilakukan oleh pemerintah daerah dapat lebih terarah. Sehingga tujuan dari pemerintahan daerah dapat tercapai. Oleh karena itu untuk mewujudkan anggaran dapat berjalan secara efektif dan efesien, penyusunan, pelaksanaan dan pelaporan anggaran harus mentaati peraturan dan perundangan-udangan yang berlaku. Proses penyusunan, pelaksanaan dan pelaporan anggaran harus mentaati peraturan dan perundangan-udangan yang berlaku diwakili dengan tanda yakni kata "aman". Kata "aman" menurut KBBI berarti bebas dari bahaya, tidak mengandung resiko. Dalam terminologi bahasa jawa berarti tenteram; damai; tenang; tidak ada keributan. Hubungan kata "aman" dengan anggaran pada pemerintah daerah dapat ditafsirkan bahwa sebuah anggaran harus bisa dipastikan tidak mengandung resiko. Artinya bahwa dalam proses perencanaan, pelaksanaan, maupun pada saat pelaporan sebuah anggaran sudah mengikuti peraturan dan perundangundangan yang berlaku.

Proses penyusunan anggaran yang mencakup pendapatan dan belanja daerah harus mengacu pada peraturan dan perundang-undangan yang berlaku, seperti undang-undang, peraturan pemerintah, keputusan menteri, peraturan daerah atau keputusan kepala daerah (Nawawi, 2015).Anggaran pada pemerintah daerah biasanya ditetapkan dalam bentuk peraturan daerah untuk satu tahun anggaran yakni Perda APBD, sehingga memiliki kekuatan hukum yang tetap. Penyusunan anggaran pada pemerintah daerah biasanya berpedoman pada Peraturan Menteri Dalam Negeri tentang Pedoman Penyusunan Anggaran Pendapatan dan Belanja Daerah, yang biasanya diterbitkan sebelum penyusunan anggaran tahun berikutnya. Sedangkan dalam pelaksanaannya, pemerintah daerah berpedoman pada Dokumen Pelaksanaan Anggaran (DPA) yang merupakan bagian tak terpisahkan dari APBD.

Kata "aman" dalam hubungannya dengan anggaran juga dapat diartikan bahwa pelaksanaan anggaran dapat dijalankan dengan baik oleh eksekutif dalam hal ini adalah Pengguna Anggaran. Tidak heran jika dalam pemerintahan daerah muncul istilah "money follow person", yang artinya uang mengikuti orang. Artinya seorang eksekutif atau pengguna anggaran yang memiliki kemampuan dalam mengelola anggaran dengan baik akan selalu dipercaya untuk mengelola anggaran yang lebih besar, meskipun ia berpindah-pindah OPD. Hal ini dilakukan agar semuanya bisa berjalan dengan aman.

Sebagai upaya pemerintah daerah untuk mewujudkan konsep aman pada anggaran diantaranya dengan mengadakan sosialisasi tentang kebijakan-kebijakan pemerintah dan peraturan perundang-undangan. Misalnya dengan bekerjasama dengan lembaga penegak hukum seperti kejaksaan dan badan pemeriksa keuangan untuk melakukan sosialisasi agar tidak terjerat pada permasalahan hukum. Anggaran merupakan alat bagi pemerintah untuk melaksanakan kebijakan-kebijakan yang sudah ditetapkan bersama antara eksekutif dan legislatif dan penggunaannya harus berdasarkan pada ketentuan hukum yang berlaku (Barata \& Trihartanto,

\footnotetext{
${ }^{8}$ Masa reses merupakan waktu yang digunakan oleh anggota dewan untuk menggali aspirasi masyarakat, khususnya konstituen pada daerah pilihan anggota dewan tersebut.
} 
2004). Oleh karena itu sejak penyusunan, pelaksanaan, dan pelaporan anggaran harus selalu berpedoman pada peraturan dan perundangan-undangan yang berlaku.

\section{c. Anggaran digunakan untuk memenuhi kepentingan eksekutif dan legislatif (uman).}

Undang-Undang Nomor 32 Tahun 2004 tentang Pemerintahan Daerah memberikan penjelasan bahwa eksekutif dan legislatif daerah memiliki kedudukan yang sejajar. Keduanya melaksanakan salah satu fungsinya secara bersama-sama yakni membuat kebijakan tentang penganggaran daerah yang kemudian ditetapkan dalam Peraturan Daerah tentang APBD. Adanya kedudukan yang sejajar dalam proses penyusunan anggaran pemerintah daerah mengakibatkan masing-masing aktor tersebut berusaha untuk "memperjuangkan" kepentingan masing-masing. Sehingga wajar jika anggaran pemerintah daerah harus dapat memenuhi kepentingan eksekutif dan legislatif. Para aktor menggunakan hak diskresi ${ }^{9}$ dan memanfaatkannya sebagai keleluasaan dalam mengalokasikan anggaran untuk kepentingan individu atau kelompok (Yamin, 2015).

"Uman", dalam terminologi bahasa jawa artinya terpenuhi. Artinya bahwa anggaran yang dibuat berdasarkan visi-misi walikota yang tertuang dalam dokumen RPJPD dan RPJMD. Anggaran seyogyanya dapat memenuhi visi-misi walikota sebagai wujud dari janji politik yang telah disampaikan kepada masyarakat pada saat kampanye pemilihan kepala daerah sebelumnya. Pernyataan bahwa anggaran memuat visi dan misi walikota disampaikan oleh Bapak Suryanto yang saat ini menjabat sebagai wakil ketua Badan Anggaran sekaligus anggota dari Partai Merah

"Anggaran harus digunakan dari visi dan misi Walikota... Terus prioritas, prioritas walikota apa? Ya itu yang harus dilaksanakan dulu...kita tidak bisa ngawur. Visi misi walikota harus tercantum di dalam anggaran..."

Hal ini juga berlaku bagi legislatif. Anggota DPRD akan selalu berusaha untuk mewujudkan aspirasi masyarakat, khususnya konstituen pada daerah pilihannya melalui program dan kegiatan yang 'dititipkan' kepada salah satu OPD. Bapak Suryanto yang saat ini menjabat sebagai wakil ketua Badan Anggaran sekaligus anggota dari Partai Merah dalam wawancaranya menyampaikan:

"Sebenarnya anggaran itu yang melaksanakan adalah pemerintah (eksekutif) dalam hal ini melalui kebijakan walikota. Tapi tidak menutup kemungkinan, kita karena sudah melakukan reses, melakukan (penjaringan)...nganu... aspirasi dari masyarakat. Ya itu kita masukkan. Kita 'titipkan' dalam pemerintahan itu. Nah pemerintah mau ndak mau harus menjalankan...Harus menjalankan, karena yang menjalankan kan sana (eksekutif). Kita tidak bisa menjalankan. Tapi kita...iki lho kampungku...iki lho uwongku durung digarap (ini lho kampungku, ini lho orangku belum dipenuhi aspirasinya).Ya... Tapi tetap dengan persetujuan Walikota..."

Bentuk terpenuhinya aspirasi masyarakat ini biasanya lebih bersifat pragmatis, Misalnya adanya program pembangunan jalan, pavingisasi, bedah rumah, bantuan modal, dan lain sebagainya. Usaha ini dilakukan sebagai upaya untuk menjaga loyalitas konstituennya. Secara formal bentuk aspirasi masyarakat yang disampaikan melalui anggota DPRD ini termuat dalam pokok-pokok pikiran (pokir) anggota DPRD. Pokir ini kemudian disampaikan dalam rapat oleh Badan Anggaran kepada kepala daerah selambat-lambatnya 5 (lima) bulan sebelum APBD ditetapkan, sebagaimana diatur dalam Peraturan Pemerintah No.16/2010 tentang Pedoman Penyusunan Peraturan DPRD yang mengatur tentang Tata Tertib DPRD

\footnotetext{
${ }^{9}$ Diskresi adalah keputusan dan/atau tindakan yang ditetapkan dan/atau dilakukan oleh pejabat pemerintahan untuk mengatasi persoalan konkret yang dihadapi dalam penyelenggaraan pemerintahan dalam hal peraturan perundangundangan yang memberikan pilihan, tidak mengatur, tidak lengkap atau tidak jelas, dan/atau adanya stagnasi pemerintahan. (UU Nomor 30 Tahun 2014 tentang Administrasi Pemerintahan. Berdasarkan Pasal 1 Angka 9 UU 30/2014)
} 
Anggaran merupakan muara dari pergulatan antara eksekutif dan legislatif. Dinamika yang terjadi selama proses penyusunan anggaran menggambarkan kepentingan eksekutif dan legislatif tercermin dalam anggaran. Dengan kata lain bahwa anggaran menjadi gambaran perilaku eksekutif dan legislatif. Anggaran adalah bentuk kekuasaan dan sekaligus sumber kekuasaan. Anggaran bisa melayani kepentingan dari pihak-pihak berwenang terhadap sumber daya yang langka, sekaligus bisa melayani pihak-pihak dari unit yang keuangannya tunduk pada anggaran yang dibuat (Razak, 2011). Anggaran digunakan untuk memenuhi kepentingan eksekutif dan legislatif (uman).

\section{Mitos Anggaran}

Mitos merupakan bentuk pesan yang diyakini kebenarannya namun sulit untuk dibuktikan. Mitos bukan ide atau konsep namun merupakkan cara bagaimana memberi makna sebuah tanda. Secara etimologis, mitos merupakan tipe wicara (type of speech). Dalam pandangan Barthes semua hal dapat menjadi mitos ketika hal itu disampaikan melalu wacana (discourses). Definisi mitos tidak ditentukan oleh objek pesannya melainkan pada cara penyampaian pesan. Wicara dalam semiotika tidak hanya terbatas pada lisan ataupun teks, namun juga termasuk fotografi, olahraga, laporan, pertunjukan, dan publisitas (Barthes, 2007).

Anggaran untuk kesejahteraan masyarakat merupakan salah satu mitos yang sampai saat ini berkembang dimasyarakat kita. Dari kacamata semiotika Barthesian dapat dilihat, bahwa anggaran untuk kesejahteraan masyarakat merupakan bentuk tautologi, yakni suatu pernyataan yang sudah menjadi kebiasaan dan tidak perlu diperdebatkan lagi. Anggaran untuk kesejahteraan rakyat adalah amanat kontitusi yang tidak dapat dibantah lagi. Oleh karena itu setiap program dan kegiatan pemerintah selalu ditujukan untuk kepentingan rakyat. Berikut hasil wawancara dengan Bapak Angga (59 tahun), Asisten Pemerintahan dan Tim Anggaran Kota Balakoma.

"Tujuan anggaran...untuk kesejahteraan masyarakat, terus kemudian untuk meningkatkan pelayanan, untuk maintenance.."

Senada dengan pernyataan bahwa anggaran itu harus digunakan untuk kesejahteraan masyarakat dan pro rakyat disampaikan oleh Bapak Fitrah (45 tahun), anggota Badan Musyawarah DPRD Kota Balakoma.

"Ya itu tadi...Anggaran itu harus pro rakyat...kita akan all out melaksanakan kewajiban kita sebagai wakil rakyat...anggaran harus dilaksanakan sesuai dengan apa itu namanya...aspirasi masyarakat...Kepentingan masyarakat itu ya didulukan lah. Memang semua anggaran itu penting sekali.. apalagi namanya... untuk halhal yang urgent."

Hal yang sama juga disampaikan oleh Bapak Suryanto, anggota DPRD yang menjadi wakil ketua badan Anggaran.

"Anggaran penting...sekali...untuk kesejahteraan masyarakat...dari masyarakat dan untuk masyarakat."

Anggaran untuk kesejahteraan rakyat adalah sebuah mitos yang selalu dikumandangkan sebagai bentuk 'pembenaran' dalam proses penyusunan anggaran. Anggaran yang disusun oleh eksekutif dan legislatif pada pemerintah daerah tidak semata-mata mengambarkan realitas yang ada yakni untuk kepentingan kesejahateraan masyarakat, namun di dalamnya juga termuat kepentingan-kepentingan pribadi, baik eksekutif maupun legislatif. Mitos bahwa anggaran digunakan untuk kesejahteraan rakyat telah menjadi bagian sebuah ideologi yang sudah ditetapkan di dalam kontitusi. Mitos anggaran untuk kesejahteraan rakyat telah menjadi sebuah paradigma yang sudah berakar lama, digunakan sebagai acuan dalam kehidupan berbangsa dan bernegara dan menjadi landasan bagi berbagai kepentingan.

Anggaran untuk kesejahteraan rakyat adalah sebuah mitos, karena anggaran tidak hanya ditujukan untuk kepentingan rakyat saja namun juga digunakan untuk memenuhi kepentingan eksekutif dan legislatif. Beberapa penelitian tentang anggaran menyebutkan bahwa proses 
penyusunan anggaran, sarat dengan kepentingan aktor penyusun anggaran yakni eksekutif dan legislatif. Aktor penyusun anggaran akan memanfaatkan posisinya baik sebagai eksekutif maupun legislatif untuk menggunakan berbagai cara dalam memenuhi kepentingannya maupun kelompoknya, sehingga kepentingan masyarakat menjadi terabaikan (Razak et al., 2011). Partisipasi masyarakat dalam proses penyusunan anggaran hanya bersifat ceremonial (Sopanah, 2012) Para aktor penyusun anggaran kurang memberikan sosialisasi kepada masyarakat, sehingga masyarakat kurang berpartipasi dalam proses penganggaran. Terjadi perilaku oportunistik dalam proses penyusunan anggaran yang dilakukan oleh legislatif untuk memenuhi kepentingannya (Abdullah, 2016). Sehingga terjadi penyimpangan manfaat anggaran dalam bentuk pelayanan publik, dan masyarakat menjadi dirugikan.

Anggaran pada pemerintah daerah ditujukan untuk kesejahteraaan rakyat merupakan bentuk mitos karena proses pencapaian kesejahteran masyarakat selalu dihubungkan dengan kuantifikasi kualitas kesejahteraan masyarakat. Kuantifikasi kualitas penurunan angka kemiskinan seringkali dijadikan dasar bagi pemerintah daerah untuk menganggarkan program dan kegiatan yang bertujuan untuk meningkatkan kesejahteraan rakyat. Namun sayangnya program dan kegiatan tersebut hanya untuk memenuhi kepentingan eksekutif dan legislatif saja. Proses penganggaran pada pemerintah seolah-olah berjalan secara 'alami' mengikuti sistem penganggaran daerah yang sudah ditetapkan. Berusaha mewujudkan aspirasi dan kesejahteraan masyarakat. Namun dibalik itu semua tersembunyi 'aspirasi-aspirasi' aktor penyusun anggaran yakni eksekutif dan legislatif. Berdasarkan hasil penelitian tentang makna anggaran pemerintah dengan metode semiotika Barthesian, maka di dapatkan keragaman makna anggaran pemerintah daerah sebagai berikut. (gambar 5).

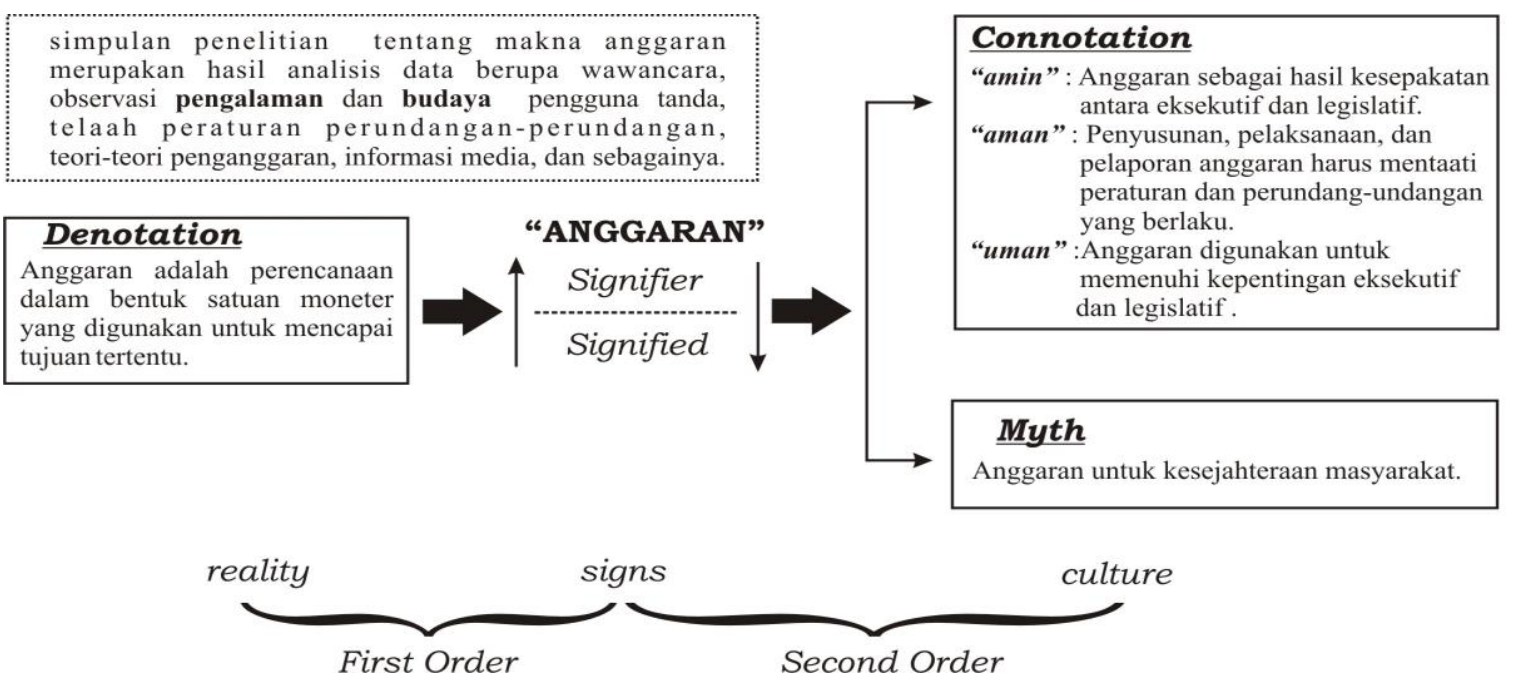

Gambar 5. Ringkasan hasil pembahasan tentang makna anggaran dengan menggunakan metode semiotika Barthesian

\section{SIMPULAN DAN SARAN}

Berdasarkan hasil pembahasan diatas, dapat disimpulkan bahwa makna denotatif anggaran pemerintah daerah adalah sebuah perencanaan yang dituangkan dalam bentuk satuan moneter untuk mencapai tujuan tertentu. Namun dibalik angka-angka yang termuat dalam anggaran tersebut tersembunyi beragam makna tentang anggaran. Adapun makna konotatif anggaran pemerintah daerah merupakan hasil kesepakatan antara eksekutif dan legislatif (amin). Penyusunan, pelaksanaan, dan pelaporan anggaran harus mentaati peraturan dan perundang-undangan yang berlaku (aman). Dan anggaran pemerintah daerah digunakan untuk memenuhi kepentingan 
eksekutif dan legislatif (uman). Sedangkan pada tataran mitos, anggaran pemerintah daerah diidentikkan sebagai usaha untuk kesejahteraan masyarakat. Dalam setiap anggaran termuat berbagai kepentingan baik kepentingan pribadi maupun kepentingan golongan. Tarik-menarik yang terjadi selama proses penganggaran menjadi bukti bahwa setiap orang memiliki tafsir yang berbeda terhadap anggaran. Latar belakang personal, dan lingkungan budaya akan mempengaruhi bagaimana seseorang menafsirkan suatu anggaran.

Pemahaman atas keragaman makna anggaran pemerintah daerah menjadi sangat penting bagi akuntansi sektor publik khususnya di bidang anggaran pemerintah daerah. Secara praktis hasil penelitian ini dapat menjadi pertimbangan bagi instansi pemerintah daerah dalam proses penyusunan anggaran di daerah. Amin, aman, uman dapat menjadi salah satu alternatif pendekatan dalam penyusunan anggaran pada pemerintah daerah. Sehingga dalam penyusunan, pelaksanaan, dan pelaporan anggaran dapat berjalan dengan efektif dan efisien serta memberikan manfaat bagi seluruh stakeholder yang terlibat dalam proses penganggaran daerah. Sedangkan secara teoritis hasil penelitian tentang makna anggaran pemerintah daerah dapat memberikan sumbangsih terhadap pengembangan keilmuan akuntansi sektor publik khususnya pada bidang anggaran pemerintah daerah melalui pendekatan semiotika Barthesian.

Penelitian ini hanya melibatkan unsur eksekutif dan legislatif sebagai informannya.Oleh karena itu, untuk penelitian berikutnya perlu kiranya melibatkan informan dari unsur yudikatif seperti kepolisian, kejaksaan dan badan pemeriksa keuangan maupun dari unsur masyarakat seperti tokoh masyarakat, tokoh LSM, dan masyarakat biasa. Sehingga didapatkan makna anggaran yang lebih beragam. Penelitian ini menggunakan semiotika Barthesian sebagai metode penelitian. semiotika Barthesian merupakan hasil dari pemikiran Roland Barthes, seorang pemikir Prancis yang banyak mengulas tentang semiotika dan budaya. Gagasan Barthes mengenai "two order of signification" tentunya memiliki kelebihan dan kekurangan untuk digunakan sebagai sebuah metode penelitian. Oleh karena itu agenda penelitian kedepan, khususnya yang menggunakan pendekatan semiotika, perlu untuk dikembangkan dengan menggunakan konsep berpikir para ahli semiotika yang lain seperti Ferdinand de Saussure, Charles S Pierce, Jean Bauldrillard, Julia Kristeva, Levi-Strauss, Umberto Eco dan lainnya.

\section{DAFTAR RUJUKAN}

Abdullah, S. 2016. Perilaku Oportunistik Legislatif Dalam Penganggaran Daerah: Pendekatan Principal-Agent Theory. Retrieved from http://www.researchgate.com

Agropolitannews. 2017. Biografi Cahyo Edi Purnomo. Retrieved from http://agropolitantv.co.id

Arfiansyah, S. 2016. Eksplorasi Makna Partisipasi Masyarakatdalam Penganggaran: Sebuah Studi Fenomenologi. Jurnal Akuntansi Aktual, Vol. 3, No, 261-271.

Aziza, K. S. 2015. Pemprov dan DPRD Harus Samakan Persepsi soal APBD. Retrieved from http://www.tekno.kompas.com

Barata, A. A., \& Trihartanto, B. 2004. Kekuasaan Pengelolaan Keuangan Negara/Daerah. Jakarta: PT. Gramedia.

Barthes, R. 1957. Myth Today. In T. A. Lavers (Ed.), Mythologies (pp. 109-159). New York: Hill and Wang.

Barthes, R. 2007. Membedah Mitos-Mitos Budaya Massa: Semiotika atau Sosiologi Tanda, Simbol, dan Representasi. Yogyakarta: Jalasutra.

Belkaoui, A. R. 1980. The Interprofessional Linguistic Communication of Accounting Concepts: An Experiment in Sociolinguistic. Journal of Accounting Research, 18 (2), Au, 362-374.

Belkaoui, A. R. 1989. Accounting and Language. Journal of Accounting Literature, Vol.8, 281292.

Chandler, D. 2007. Semiotics The Basics. 2nd Edition. Routledge 2 Park

Square, Milton Park, Abingdon, Oxon OX14 4RN 
Creswell, J. 2014. Penelitian Kualitatif \& Desain Riset: Memilih diantara Lima Pendekatan. Yogyakarta: Pustaka Pelajar.

Djamhuri, A. 2012. Ilmu Pengetahuan Sosial dan Berbagai Paradigma dalam Kajian Akuntansi. Jurnal Akuntansi Multiparadigma, Vol. 2 No., 147- 185.

Erina, N. P. D., \& Suartana, W. 2016. Pengaruh Partisipasi Penganggaran, Penekanan Anggaran, Kapasitas Individu, dan Kejelasan Sasaran Anggaran Pada Senjangan Anggaran. E-Jurnal Akuntansi Universitas Udayana, Vol.15.2., 973-1000.

Fakhry, Syarifuddin, \& Said, D. 2014. Budget Process Pemerintahan Daerah: Menelisik Nilai Kemandaran Atas Perilaku Aktor Anggaran. Jurnal Analisis, 3(2), 189-194.

Fiske, J. 2007. Cultural and Communication Studies Sebuah Pengantar Paling Komprehensifitle. Bandung: Jalasutra.

Fontana, F. B. 2013. A study about Accounting Publications from a Semiotic Focus. Journal of Education and Research in Accounting. REPeC, Brasília, v. 7, n.1, 5-19.

Gordon, T. 2002. Saussure. Yogyakarta: Kanisius.

Halim, A., \& Kusufi, M. S. 2012. Akuntansi Sektor Publik: Teori, Konsep, dan Aplikasi. Jakarta: Salemba Empat.

Hendriksen, E., \& Van Breda, M. 1992. Accounting Theory (5th ed.). Homewood, IL: Irwin.

Hoed, B. 2011. Semiotik dan Dinamika Sosial Budaya. Jakarta: Komunitas Bambu.

Jawa Pos. (2017a). Dana Parpol Naik jadi Rp 1.000 Per Suara, Ah...Kecil itu. Retrieved from https://www.jpnn.com

Jawa Pos. 2017). Perintah Jokowi Hindari Hujatan dan Fitnah Diamini DPR. Retrieved from http://www.jpnn.com

Nawawi, J. 2015.Analisis Hubungan DPRD dan Pemerintah Daerah dalam Pembuatan Kebijakan Kemiskinan di Provinsi Sulawesi Barat. Government: Jurnal Ilmu Pemerintahan. Volume 8, Nomor 1, Januari 2015 (27-42).

Pasoloran, O. 2016. Narsisisme Dana Aspirasi Masyarakat Dalam Penganggaran Daerah: Kajian Etno-Semiotika Berbasis Filsafat Barthesian. In Simposium Nasional Akuntansi XIX Lampung.

Piliang, Yasraf Amir. 1998.Sebuah Dunia yang Dilipat: Realitas Kebudayaan Menjelang Milenium Ketiga dan Matinya Posmodernisme. Bandung: Penerbit Mizan

Rahardjo, S. N. 2009. Pengaruh Leadership Style dan Kultur Paternalistik Terhadap Efektivitas Anggaran Partisipasi Dalam PeningkatanKinerja Manajerial. Jurnal Akuntansi Dan Auditing, Vol. 5

Razak, A., Ludigdo, U., Sukoharsono, E. G., \& Thoyib, A. 2011. Perilaku Kuasa Eksekutif Dan Legisiatif dalam Proses Penyusunan Anggaran Pemerintahan Daerah: Jurnal Akuntansi Multiparadigma, 2, 369-540.

Razak, A. 2011. Perilaku Kuasa Eksekutif dan Legislatif dalam Proses Penyusunan Anggaran Pemerintahan Daerah: Perspektif Interaksionisme Simbolik (Studi Kasus di Pemerintah Kota Mayapada). Disertasi. Pascasarjana Universitas Barwijaya Malang

Riharjo, I. B., \& Isnadi. 2010. Perilaku Oportunistik Pejabat Eksekutif dalam Penyusunan APBD (Bukti Empiris Atas Penggunaan Penerimaan Sumber Daya Alam). Ekuitas, Vol 14, No, 389 - 411. http://doi.org/http://dx.doi.org/10.24034/j25485024.y2010.v14.i3

Republik Indonesia, Peraturan Pemerintah No. 16 tahun 2010 tentang Pedoman Penyusunan Peraturan Dewan Perwakilan Rakyat Daerah yang mengatur tentang Tata Tertib Dewan Perwakilan Rakyat Daerah.

Republik Indonesia, Permendagri Nomor 31 tahun 2016 tentang Pedoman Penyusunan Anggaran Pendapatan dan belanja daerah Tahun Anggaran 2017

Republik Indonesia, Undang-Undang Nomor 23 Tahun 2014 Tentang Pemerintahan Daerah. Republik Indonesia, Undang-Undang Nomor 30 Tahun 2014 tentang Administrasi Pemerintahan. 
Sopanah. 2009. Studi Fenomenologis: Menguak Partisipasi Masyarakat Dalam Proses Penyusunan APBD di Kota Malang. In Simposium Nasional Akuntansi (SNA) 12 Tanggal 4-6 November 2009. Palembang.

Sopanah. 2012. Ceremonial Budgeting dalam Perencanaan Penganggaran Daerah: Sebuah Keindahan yang Menipu. Jurnal Akuntansi Manajemen, 73-84.

Sunardi, S. 2007. Semiotika Negativa. Yogyakarta: Kanal.

Usman, E., \& Paranoan, S. 2013. Anggaran Partisipastif dalam Menunjang Kinerja Aparatur Pemerintah Daerah. Jurnal Akuntansi Multiparadigma, 4(1), 127-135. Retrieved from www.jamal.ub.ac.id

Wahyuningsih, S., \& Pramuka, B. A. 2012. Determinan Partisipasi Penganggaran dan Pengaruhnya Terhadap Kinerja Manajerial Aparat Pemerintah Daerah Kabupaten Banyumas. Jurnal Akuntansi \& Auditing, Volume 9/N.

Wance, M., \& Suranto. 2017. Pola Relasi Eksekutif dan Legislatif pada Penyusunan Legislasi Daerah (Studi di Pembahasan APBD Kabupaten Buru Selatan 2015). Journal of Governance And Public Policy, Vol. 4 No.

Yamin, N Y. 2015.Aksi Kuasa Aktor Dalam Penganggaran Daerah: Perspektif Habermasian. Disertasi. Pascasarjana Universitas Barwijaya Malang

Yanuarisa, Y., Rosidi, \& Irianto, G. 2014. Fenomenologi Transendental dalam Transparansi dan Akuntabilitas Performance Based Budgeting. Jurnal Aplikasi Manajemen, 12 (2). 